\title{
Peran Pola Asuh Otoritatif Orang Tua, Pendidikan Orang Tua dan Jumlah Saudara Terhadap Kemandirian Anak
}

\author{
Wasinah \\ TK Tahunan Umbulharjo Yogyakarta \\ Jl. Garuda Balai, Kampung Tahunan, Umbulharjo, Yogyakarta, Indonesia \\ Email:anfiksan@yahoo.co.id
}

\begin{abstract}
This study aims to determine the role of authoritative parenting, parents' education, number of siblings toward independence at an early age children in kindergarten IT Salman Al Farisi. This research used quantitative approach with correlation type. The research subject was 53 students of kindergarten IT Salman Al Farisi Yogyakarta. Data collection instruments used in the form of guidelines for observation of independence, authoritative parenting scale, parents' education questionnaire, and the questionnaire of siblings numbers. Data analysis techniques used multiple regression. The results showed that there were positive and highly significant role between authoritative parenting, parents' education, and number of siblings toward independence together amounted to $39.6 \%$. Specifically there is a positive role and very significant between authoritative parenting towards independence with a contribution of $27.2 \%$, there is a positive role and significant correlation between parents' education towards independence with a contribution of $21.2 \%$, there is a positive role and very significant between number of siblings toward independence with contributions $51.6 \%$. The results of this study can be used as information for guidance and counseling teachers in providing information to parents about appropriate parenting for children to make them grow and develop optimally.
\end{abstract}

Keywords: authoritative parenting, parents education, sibling numbers role, independence

\begin{abstract}
Penelitian ini bertujuan untuk mengetahui peran pola asuh otoritatif orang tua, pendidikan orang tua, dan jumlah saudara terhadap kemandirian pada anak usia dini di TK IT Salman Al Farisi. Pendekatan penelitian yang digunakan kuantitatif dengan jenis korelasi. Subjek penelitian sejumlah 53 siswa TK IT Salman Al Farisi Yogyakarta. Instrumen pengumpulan data yang digunakan berupa pedoman observasi kemandirian, skala pola asuh otoritatif orang tua, angket pendidikan orang tua, dan angket jumlah saudara. Teknik analisis data yang digunakan regresi ganda. Hasil penelitian menunjukkan bahwa terdapat peran positif dan sangat signifikan antara pola asuh otoritatif orangtua, pendidikan orangtua, dan jumlah saudara terhadap kemandirian secara bersamasama sebesar $39,6 \%$. Secara spesifik terdapat peran positif dan sangat signifikan antara pola asuh otoritatif orangtua terhadap kemandirian dengan kontribusi sebesar $27.2 \%$, terdapat peran positif dan signifikan antara pendidikan orangtua terhadap kemandirian dengan kontribusi sebesar $21.2 \%$, terdapat peran positif dan sangat signifikan antara jumlah saudara terhadap kemandirian dengan kontribusi terbesar $51.6 \%$. Hasil penelitian ini dapat dijadikan sebagai informasi bagi guru bimbingan dan konseling dalam memberikan layanan informasi kepada orangtua tentang pola asuh yang tepat agar anak dapat tumbuh dan berkembang secara optimal.
\end{abstract}

Kata kunci: pola asuh otoritatif orangtua, pendidikan orangtua, peran jumlah saudara, kemandirian

\section{Pendahuluan}

Kemandirian atau otonomi adalah kemampuan seseorang untuk mengendalikan dan mengatur pikiran, perasaan dan tindakan sendiri secara bebas serta berusaha sendiri untuk mengatasi perasaan-perasaan malu dan ragu-ragu (Desmita: 2013). Dengan otonomi tersebut, anak diharapkan lebih bertanggungjawab terhadap dirinya sendiri tanpa menggantungkan orang lain.Kemandirian merupakan salah satu ketrampilan yang penting untuk dikuasai oleh anak sebelum ia memasuki sekolah dasar (Dirjen PAUDNI: 2012). Perkembangan kemandirian anak usia dini merupakan pondasi dasar untuk perkembangan kemandirian pada jennjang pendidikan selanjutnya. Anak yang telah memiliki kemandirian sejak dini akan mudah bersosialisasi dengan lingkungannya. Sebaliknya bagi anak yang memiliki tingkat kemandirian yang kurang akan menghambat dalam perkembangan dan penyesuaian diri pada lingkungannya.

Anak sebagai tanggungjawab orangtua memiliki tugas dan kewajiban yang perlu dilaksanakan. Salah satu tugas wajib bagi orangtua adalah membantu memandirikan anak dalam menjalani kehidupan. Menurut Fatimah 


\section{POLA ASUH OTORITATIF ORANGTUA, PENDIDIKAN ORANGTUA, JUMLAH SAUDARA, KEMANDIRIAN}

(2008), mandiri atau sering disebut juga berdiri di atas kaki sendiri merupakan kemampuan seseorang untuk tidak bergantung pada orang lain serta bertanggung jawab atas apa yang dilakukannya. Anak yang mandiri adalah anak yang mengetahui akan tugas dan kewajibannya serta dapat mempertanggungjawabkan semua yang dikperbuatnya

Anak adalah amanah yang harus dididik sebaik mungkin agar mereka mengenal dan takut pada Allah.Anak merupakan titipan Allah Tuhan Yang Maha Kuasa yang harus diterima dengan setulus hati dan apa adanya (Muthmainnah, 2012). Orang tua bertanggungjawab untuk membimbing dan mendidik agar kelak menjadi generasi bangsa yang mandiri, bertanggung jawab, dan dapat menjadi insan yang sanggup untuk menyesuaikan diri dengan lingkungannya dan beraklak mulia.

Tiga tahun di awal kehidupan manusia diyakini sebagai masa yang sangat penting bahkan lebih penting untuk mengembangkan kemampuan berinteraksi dengan orang lain, mengontrol dan memiliki kemandirian untuk pembentukan dasar kualitas kehidupan selanjutnya. Oleh sebab itu anak usia dini dipandang sangat penting untuk mendapatkan perawatan, pengasuhan, dan stimulasi yang tepat agar potensi-potensi yang terbawa dari sejak dalam kandungan dapat teroptimalkan. Menurut Fadlillah \& Khorida (2013), usia dini merupakan usia emas (goldenage) dimana pada masa ini anak memiliki seluruh potensi yang harus dikembangkan.

Pola asuh yang diterapkan oleh masingmasing keluarga dipengaruhi oleh latar belakang budaya, pendidikan, jumlah saudara, strata sosial, lingkungan, ataupun sistem keluarga. Sistem pengasuhan yang diberikan oleh orang tua secara berbeda-beda tersebut menjadikan kepribadian anak yang berbeda pula. Situasi yang bervariasi akan memengaruhi perkembangan anak dan memengaruhi murid di dalam dan di luar kelas (Santrock, 2004) .

Seiring berjalannya waktu kemampuan anak terus berkembang, baik dalam hal sikap, kemampuan berpikir, kemampuan berkomunikasi, kemampuan bersosialisasi, dan kemampuan yang lainnya. Suyanto (2005) berpendapat bahwa interaksi dengan anak lain dapat mendorong anak mulai mengenal adanya perbedaan pola pikir dan keinginan anak lain. Pada usia lima tahun pada umumnya anak sudah dapat bermain secara kooperatif. Anak usia 2-6 tahun telah dapat mengembangkan rasa percaya diri, mau dilepas dari ikatan orang tua, dan mempu menguasai keterampilan diri. Anak yang diberikan kebebasan bergerak, diajak untuk berlatih dan bersosialisasi dengan ingkunga, serta ketrampilannya maka anak akan dapat berkembang dan dapat merasa berhasil. Sebaliknya bila anak tidak dilatih untuk menguasai diri akan menimbulkan rasa rendah diri.

Orangtua memberikan pengaruh dalam perkembangan anak. Wade \& Tavris (2007) mengemukakan bahwa orang tua memang mempengaruhi anak-anaknya dalam berbagai hal. Mereka mempengaruhi keyakinan anak-anak mereka, minat intelektual dan pekerjaan, keyakinan diri atau ketidak percayaan diri, keyakinan terhadap pandangan feminim atau maskulin yang tradisional dan modern, serta mempengaruhi kesediaan untuk menolong orang lain ketrampilan dan nilai. Orang tua adalah agen pengubah yang mampu mengubah anak untuk berubah haluan ke arah yang lebih sehat.

Namun pada kenyataannya ada gejala yang mengarah kepada sikap ketidakmandirian anak.Anaksulituntuk anak mengatasi perasaanperasaan ragu dan malu. Berdasarkan hasil wawancara dengan kepala sekolah dan dewan guru, di awal tahun pembelajaran di TK IT Salman Al Farisi Kecamatan Umbulharjo Yogyakarta terdapat anak yang mengarah pada ketidakmandirian anak.Haltersebut ditunjukkan oleh anak didik yang kurang bertanggungjawab pada dirinya sendiri, seringnya meminta tolong kepada orang lain, tidak mau ditinggal orang tua ketika di sekolah, mudah menangis, dan menyerahkan tugas pada guru sebelum selesai dikerjakan.

Ketidakmandirian anak pada pembahasan sebelumnya, tidak disebabkan oleh satu faktor saja, menurut para ahli kemandirian dipengaruhi dari banyak faktor. Desmita (2010) berpendapat bahwa faktor yang mempengaruhimandirian anak antara lain: pola asuh, pendidikan orang tua, jumlah saudara, dukungan teman sebaya, keutuhan keluarga, sebaliknya suasana rumah tangga tanpa kehangatan, komunikasi yang berlaku hanya satu arah saja merupakan salah 
satu faktor anak memiliki kemandirian yang buruk.Kurangnya perhatian dan kasihsayang dari orang tua, Anak yang selalu disalahkan oleh orang tua, selalu mendapatkan hukuman, maka anak akan merasa ragu dan malu sehingga perkembangannya akan terhambat khususnya perkembangan kemandirian anak.

Kemandirian tidak akan lepas dari campur tangan orang dewasa yang ada di dalam keluarga. Pembimbingandan kesabaran orang tua yang diberikan kepada anak dengan penuhkasih sayang akan membawa anak ke dalam kesuksesan diperkembangan anak selanjutnya. Kartono (2013), mengatakan keluarga sebagai unit sosial terkecil memberikan stempel dan pondasi dasar bagi perkembangan anak. Kebiasaan yang dilakukan setiap hari oleh orang tua maupun saudara-saudaranya bisa memberikan pengaruh terhadap lingkungan, khususnya kepada anakanaknya.

Berdasarkan pendapat para ahli di atas dapat disimpulkan bahwa pola asuh orang tua, pendidikan orang tua, dan jumlah saudara berperan dalam perkembangan kemandirian anak. Bimbingan, kasih sayang, komunikasi yang timbal balik dari orang tua, pengetahuan, pengalaman orang tua, jumlah saudara yang hangat, selalu memberikan kebebasan kepada anak, akan mendorong anak untuk berbuat tanpa ragu-ragu sehingga anak tanpa malu-malu bisa melaksanakan tugasnya tanpa menggantungkan orang lain. Sebaliknya pola asuh, bimbingan, kasih sayang yang memihak, serta pengetahuan dan pengalaman yang kurang, tidak adanya campur tangan saudara untuk bermain dan belajar akan menghambat perkembangan kemandirian anak.

Penelitian ini bertujuan untuk mengetahui peran pola asuh otoritatif orang tua, pendidikan orang tua, dan jumlah saudara terhadap kemandirian pada anak usia dini. Kemandirian pada anak usia dini perlu diketahui agar anak akan terhindar dari sifat ketergantungan pada orang lain, dan penting bagi anak untuk dapat menumbuhkan keberanian dan motivasi untuk terus mengekspresikan pengetahuan-pengetahuan baru. Berdasarkan berbagai uraian tersebut, penelitian ini dikhusukan pada peran pola asuh otoritatif orangtua yang berhubungan dengan pendidikan dan jumlah saudara terhadap kemandirian anak. Hasil penelitian ini dapat dijadikan sebagai informasi bagi guru bimbingan dan konseling dalam memberikan layanan informasi kepada orangtua tentang pola asuh yang tepat agar anak dapat tumbuh dan berkembang secara optimal.

\section{Kajian Literatur}

\section{Kemandirian}

Setiap anak memiliki kemandirian yang dalam diri yang dapat dikembangkan dengan maksimal. Erikson (1963) menyebut kemandirian dengan istilah otonomi. Kemandirian atau otonomi adalah kemampuan seseorang untuk menentukan kebebasan ekspresi diri, kebebasan dari penindasan, kemampuan mengontrol diri tanpa kehilangan harga diri, munculnya rasa percaya diri, niat yang baik dan kebanggaan, sehingga dapat mengatasi keraguan dan rasa malu. Menurut Erikson, kemandirian atau otonomi akan tumbuh ketika seseorang mampu mengatasi rasa malu dan ragu-ragu, yang ini juga dipengaruhi oleh pola asuh. Pola asuh yang diberikan oleh orang dewasa sekeliling anak akan memberikan keyakinan dan harapan bahwa otonomi atau kemandirian akan tumbuh pada anak untuk kehidupan dikemudian hari. Hurlock(1978), berpendapat kemandirian adalah kemampuan seseorang untuk menilai diri mereka sendiri secara realistis, dapat menerima dan mengendalikan sikap perilakunya, hal ini yang berhubungan dengan sifat malu, kecemburuan, kemurungan, dan ketergantungan yang berlebihan. Tidak mudah dipengaruhi oleh orang lain, bersikap sportif dalam persaingan maupun konflik dan dapat bekerja sama dengan orang lain serta bertanggungjawab yaitu kesediaan memikul bagian bebannya. Jess \& Gregory (2010), berpendapatkemandirian adalah otonomi versus rasa malu dan ragu. Anak yang terlalu sedikit mengembangkan otonomi akan mendapatkan kesulitan ditahap-tahap yang akan datang dan kekurangan kekuatan dasar akan tahapan-tahapan selanjutnya. Konflik antara otonomi dengan rasa malu dan ragu menjadi krisis psikososial utama di masa kanak-kanak awal. Bimbingan orang tua yang menanamkan rasa malu terhadap anak seperti cemoohan dan lebel yang sering diberikan kepada anaknya akan menghambat perkembangan kemandirian anak. 


\section{POLA ASUH OTORITATIF ORANGTUA, PENDIDIKAN ORANGTUA, JUMLAH SAUDARA, KEMANDIRIAN}

Papalia dan Filman (2009) berpendapat kemandirian atau otonomi adalah tahap kedua dalam perkembangan, otonomi versus rasa malu dan ragu (autonomy versus shame and doubt), yang ditandai dengan pengertian dari kontrol eksternal ke kontrol diri, anak mulai mengganti penilaian dari orang lain dengan penilaian mereka sendiri. Rasa malu dan ragu menjadi berguna untuk membantu mereka mengenali batasanbatasan kebutuhan.

Kemandirian seorang anak tidak akan lepas dari peran serta keluarga. Anak yang terlalu dikendalikan atau dihukum terlalu keras akan mengembangkan rasa malu dan ragu. Santrock(2009) mengemukakan kemandirian merupakan isu yang penting pada tahun kedua akehidupan. Tahap otonomi versus rasa malu dan ragu-ragu memiliki implikasi yang penting bagi perkembangan kemandirian dan identitas selama masa remaja. Kemandirian memiliki beberapa aspek yang perlu dipahami. Menurut Desmita (2013) aspek-aspek kemandirian adalah sebagai berikut: Pertama, motivasi untuk bersaing. Kedua, pengambilan keputusan. Ketiga, memiliki kepercayaan diri. Keempat, bertanggung jawab. Banyak faktor yang dapat mempengaruhi perkembangan kemandirian individu seorang anak. Adapun faktor-faktor tersebut adalah sebagai berikut.

\section{Pola Asuh Otoritatif Orang Tua}

Cara mendidik dan membimbing anak dalam keluarga merupakan faktor keberhasilan untuk menentukan tinggi rendahnya kemandirian anak. Menurut Desmita (2010); hubungan orang tuaanak, yang merujuk pada iklim hubungan sosial dalam keluarga, penerapan aturan, pengakuan orang tua, kelancaran komunikasi, pemberian hadiah dan hukuman. Semakin tinggi pula pola asuh otoritatif (authoritative) orang tua semakin mambuat anak memiliki taraf kemandirian yang tinggi dan sebaliknya semakin rendah taraf kemandirian anak semakin rendah pula pola asuh otoritatif (authoritative) orang tua.

Orang tua bersikap hangat kepada anaknya, adanya jalinan komunikasi timbal balik antara orang tua dan anak, orang tua mendukung perkembangan individu anak, serta adanya aturan dan kebebasan yang diberikan kepada anak tetapi masih dalam kontrol orang tua. Menurut Papalia\& Feldman (2009), Pola Asuh orang tua yang otoritatif adalah orang tua yang menghargai individualitas anak tetapi juga menekankan batasan-batasan sosial. Pengasuhan terkait dengan hubungan antara seorang ayah dan seorang ibu yang mempengaruhi bagaimana cara orang tua tersebut menghadapi anak-anaknya. Peran orang tua dalam mengasuh anak dalam masa kehidupannya sangat penting.

Persepsi terhadap pola asuh otoritatif adalah penilaian anak terhadap sikap orang tua yang mendorong anak untuk lebih bebas tetapi tetap memberikan batasan dan mengendalikan tindakan-tindakan anak, komunikasi timbal balik bisa langsung dengan bebas dan mandiri, orang tua bersikap hangat dan sikap membesarkan hati anak, suasana terbuka dan kondusif yang ada pada pola asuh otoritatif menjadikan remaja lebih berkembang serta memiliki kemampuan menghadapi konflik yang terjadi dengan orang lain (Santrock: 2009). Menurut Baumrind (dalam Papalia Olds: 2009) aspek-aspek pola asuh otoritatiforang tua adalah penerapan peraturan, pengakuan orang tua, kelancaran komunikasi, pemberian hadian dan hukuman.

Pendidikan yang dimiliki oleh orang tua baik yang memilki tanda kelulusan maupun yang tidak mempunyai tanda kelulusan. Muhibbin (2010) berpendapat bahwa pendidikan dapat berlangsung secara informal dan nonformal disamping secara formal seperti pendidikan sekolah/ madrasah dan institusi-institusi lainnya. Menurut Suwarno (1982), pendidikan pada umumnya berarti bimbingan yang diberikan oleh seseorang terhadap perkembangan orang lain, menuju kearah suatu cita-cita tertentu. Seseorang mendapatkan pendidikan untuk suatu tujuan hidup sesuai dengan kemampuan individu masing-masing.

Orang tua merupakan pendidik yang utama dan pertama dalam keluarga, dengan pendidikan maupun pengetahuan yang luas orang tua akan memberikan bimbingan kepada anak-anaknya dengan menggunakan metode yang bervariasi sehingga akan mempermudah anak-anaknya menerima pesan-pesan yang diberikannya. Menurut Daradjat (2011) pendidikan orang tua merupakan suatu pengetahuan yang dipergunakan untuk memberikan bimbingan kepada anak sebagai tanggungjawabnya karena anak adalah amanah yang diberikan oleh Allah SWT yang dibebankan kepada mereka. 
Saudaraadalah orang yang seibu sebapa ataupun yang seibu atau sebapa saja. jumlah anak yang ada di keluarga baik laki-laki maupun perempuan yang satu ibu, satu bapak, adik atau kakak. Sedangkan kandung adalah pundi-pundi atau kantong peranakan (Kamus Besar Bahasa Indonesia: 2013). Saudara kandung adalah anak laki-laki maupun perempuan yang lahir dari kandungan seorang ibu dengan satu bapak saja. Santrock (2002), berpendapat jumlah saudara kandung mempengaruhi dalam proses sosialisasi anak dapat lebih kuat dibandingkan orang tua. Saudara kandung dapat memahami masalahmasalah anak dan dapat berkomunikasi secara lebih efektif dari pada orang tua. saudara kandung dapat lebih berpengaruh dalam proses sosialisasi dari pada rang tua. Anak yang lebih tua kadang bereaksi secara negatif terhadap kehadiran adik yang baru lahir. Reaksi tersebut disebabkan rasa cemburu ketika ibu memberikan perhatian kepada adiknya. Sebaliknya dalam posisi positifnya adik sering kali menjadikan kakaknya sebagai dasar rasa aman untuk melakukan eksplorasi kompetensi yang dimiliki dan melakukan penyesuaian diri ketika teman sebaya mengabaikan dirinya. Santrock (2002) mengatakan, Saudara yang paling tua diharapkan berlatih mengendalikan diri dan memperlihatkan tanggung jawab dalam berinteraksi dengan saudara-saudaranya yang lebih muda.

Hubungan saudara kakak dan adik saling memberi rasa aman dan mengajarkan kepada anak-anak bagaimana cara memperlihatkan kasih sayang kepada orang lain serta melaksanakan peran-peran tertentu sesuai dengan peran seksnya. Harlock (2002) Hubungan antar saudara merupakan faktor yang penting dalam perkembangan pribadi dan perkembangan sosial. Pertengkaran antar saudara memberikan pengalaman belajar yang berharga bagi anak, dari pertengkaran anak menemukan bahwa anak-anak lain ada yang mau dan tidak mau memberikan toleransi serta anak belajar menjadi ksatria yang baik.

Konflik dan persaingan dalam keluarga merupakan pola utama antara saudara kandung di masa kanak-kanak awal. Papalia (2009) menyatakan konflik-konflik saudara kandung dapat menjadi alat untuk memahami hubungan sosial. Dengan adanya persaingan anak akan belajar berbagai ketrampilan untuk mempertahankan haknya dalam keluarga maupun kehidupan selanjutnya. Pembelajaran serta kasih sayang yang diberikan oleh saudara di dalam keluarga akan menjadi pondasi bagi anak untuk bersosialisasi di luar rumah. Pembelajaran yang didapat akan membantu anak untuk mengenal dan mengetahui tentang kebutuhan anak untuk menyesuaikan diri dengan lingkungannya.

\section{Pendidikan Orang Tua}

Gaya orangtua dalam mendidik anak tidak terlepas dari latar belakang pendidikan orangtua. Gunarsa (2004), berpendapat bahwa tingkat pendidikan orang tua baik secara langsung maupun tidak langsung akan mempengaruhi komunikasi antara orang tua dan anak dalam lingkungan keluarga. Pendidikan orang tua yang lebih tinggi memiliki daya yang lebih besar, baik pendapatan, waktu, tenaga, dan jaringan kontak yang memungkinkan mereka terlibat lebih jauh dalam pendidikan anak. Keyakinan orang tua yang memiliki pendidikan lebih tinggi akan memberikan nilai, dan tujuan tentang pengasuhan dengan menggunakan model dan ketrampilan serta strategi dalam pemecahan masalah yang ada secara efektif dan dalam suasana yang kondusif dibandingkan dengan anak yang mempunyai orang tua yang memiliki pendidikan rendah.

\section{Peran Jumlah Saudara dalam Perkembangan Anak}

Jumlah saudara merupakan salah satu faktor yang mempengaruhi perkembangan kepribadian pada anak. Harlock (1980), berpendapat jumlah kelahiran anak dalam keluarga dapat mempengaruhi perkembangan kepribadian dan sosial anak. Hubungan yang menyenangkan antara saudara satu dengan saudara yang lainnya mulai berkurang dengan berjalannya waktu dan bertambahnya umur anak. Pertentangan dan pergesekan antar saudara merupakan faktor pembantu dalam perkembangan kepribadian dan sosial anak. Dari saudaranya mereka belajar menilai perilakunya sendiri. persaingan yang sehat antar saudara kandung akan tumbuh sebagai individu yang mandiri. Santrock (2002), berpendapat jumlah saudara kandung mempengaruhi dalam proses sosialisasi anak dapat lebih kuat dibandingkan orang tua. Saudara kandung dapat memahami masalah-masalah anak dan dapat berkomunikasi secara lebih efektif dari 


\section{POLA ASUH OTORITATIF ORANGTUA, PENDIDIKAN ORANGTUA, JUMLAH SAUDARA, KEMANDIRIAN}

pada orang tua. Saudara kandung dapat lebih berpengaruh dalam proses sosialisasi dari pada rang tua. Anak yang lebih tua kadang bereaksi secara negatif terhadap kehadiran adik yang baru lahir. Reaksi tersebut disebabkan rasa cemburu ketika ibu memberikan perhatian kepada adiknya. Sebaliknya dalam posisi positifnya adik sering kali menjadikan kakaknya sebagai dasar rasa aman untuk melakukan eksplorasi kompetensi yang dimiliki dan melakukan penyesuaian diri ketika teman sebaya mengabaikan dirinya.

\section{Metode Penelitian}

Subyek padapenelitian ini adalah anak usia dini yang terdaftar pada TK Salman Al Farisi Umbulharjo Yogyakarta, kelompok "B" berjumlah 53 anak didik, berumur 5 sampai 6 tahun, terdiri dari anak laki-laki: 27 anak, perempuan: 26 anak serta anak yang terdaftar pada tahun pembelajaran 2014/2015.

Metode pengumpulan data dalam penelitian ini menggunakan skala psikologi yaitu lembar observasi kemandirian, skala pola asuh otoritatif orang tua, angket pendidikan orang tua, dan angket jumlah saudara. Teknik analisis data yang digunakan adalah regresi ganda untuk mengetahui hubungan antara variabel-variabel (X) dan variabel (Y).

Pola asuh otoritatif orang tua meliputi empat aspek antara lain: penerapan peraturan, pengakuan orang tua, kelancaran komunikasi, pemberian hadiah dan hukuman. Dalam variabel pendidikan orang tua, peneliti memberikan skor data pada pendidikan orang tua, dengan menggunakan kriteria penilaian yang telah ditentukan sebelumnya yaitu: (1) untuk orang tua yang tidak sekolah atau SD sederajat, diberi skor 1; (2) untuk orang tua yang berpendidikan SLTP sederajat, diberi skor 2, (3) untuk orang tua yang berpendidikan SLTA sederajat, diberi skor 3, dan (4) untuk orang tua yang berpendidikan PT sederajat, diberi skor 4.

Dalam variabel jumlah saudara, peneliti memberikan skor data pada jumlah saudara, dengan menggunakan kriteria penilaian yang sesuai dengan jumlah anak dalam keluarga yang ditulis pada angket oleh orang tua yaitu: 1) Untuk anak yang tidak mempunyai saudara diberi skor 1 ; 2) Untuk yang mempunyai saudara satu, diberi skor 2; 3) Untuk yang mempunyai saudara dua, diberi skor 3; 4) Untuk yang mempunyai saudara tiga atau lebih, diberi skor 4 .

\section{Hasil dan Pembahasan}

Berikut disajikan data kemandirian siswa, data pola asuh otoritatif, data kategori pendidikan orangtua, data kategori jumlah saudara. Data tentang kemandirian siswa dapat dilihat pada tabel 1.

Tabel 1.

Kategori Kemandirian

\begin{tabular}{lccc}
\hline & Frequency & Percent & $\begin{array}{c}\text { Cumulative } \\
\text { percent }\end{array}$ \\
\hline Tinggi & 9 & 17.0 & 17.0 \\
Sedang & 38 & 71.7 & 88.7 \\
Rendah & 6 & 11.3 & 100.0 \\
Total & 53 & 100. & \\
\hline
\end{tabular}

Selanjutnya, data tentang pola asuh otoritatif orangtua dapat dilihat pada tabel 2.

Tabel 2.

Kategori Pola Asuh Otoritatif Orangtua

\begin{tabular}{llcc}
\hline & Frequency & Percent & $\begin{array}{c}\text { Cumulative } \\
\text { Precent }\end{array}$ \\
\hline Tinggi & 10 & 18.9 & 18.9 \\
Sedang & 34 & 64.2 & 83.0 \\
Rendah & 9 & 17.0 & 100.0 \\
Total & 53 & 100.0 & \\
\hline
\end{tabular}

Kategorisasi pendidikan orangtua dapat dilihat pada tabel 3 .

Tabel 3.

Kategori Pendidikan Orang Tua

\begin{tabular}{lll}
\hline $\begin{array}{c}\text { Pendidikan Orang } \\
\text { Tua }\end{array}$ & Frekuensi & Percent \\
\hline 6 & 7 & 13.21 \\
7 & 11 & 20.75 \\
8 & 35 & 66.04 \\
Total & 53 & 100 \\
\hline
\end{tabular}

Selanjutnya kategorisasi jumlah saudara dapat dilihat pada tabel 4 . 
Tabel 4.

Kategori Jumlah Saudara

\begin{tabular}{lll}
\hline $\begin{array}{l}\text { Jumlah } \\
\text { saudara }\end{array}$ & Frekuensi & Persen \\
\hline 0 & 5 & 9.43 \\
1 & 21 & 39,62 \\
2 & 17 & 32.08 \\
$3<\ldots$ & 10 & 18,87 \\
Total & 53 & 100 \\
\hline
\end{tabular}

Berdasarkan data kategorisasi pada masingmasing variabel yang telah digambarkan, selanjutnya dijelaskan hasil uji kolmogorof untu menguji sebaran normalitas .Hasil uji normalitas menunjukkan bahwa masing-masing variabel mempunyai nilai Kolmogorov-Smirnov Z dengan $\mathrm{p}>0,05$. yaitu kemandirian 0,113, pola asuh orangtua 0,669 , pendidikan orangtua 0,067 , dan jumlah saudara 0,088. Berdasarkan hal tersebut maka dapat disimpulkan bahwa residual telah memenuhi asumsi distribusi normal

Berdasakan hasil uji linieritas nilai signifikansi antara pola asuh orangtua terhadap kemandirian adalah sebesar 0,010. Oleh karena $\mathrm{p}$ $<0,05(0,010<0,05)$, maka uji asumsi liniertas terpenuhi.Nilai signifikansi antara kemandirian dengan pendidikan orangtuaadalah sebesar 0,005 . Oleh karena $\mathrm{p}<0,05$ maka uji asumsi liniertas terpenuhi.nilai signifikansi antara Kemandirian dengan Jumlah Saudaraadalah sebesar 0,000. Oleh karena sig. $<0,01,(0,000<0,01)$, maka uji asumsi liniertas terpenuhi.

Hasiluji multikolinieritas menunjukkan bahwa nilai VIF semua variabel bebas yaitu pola asuh otoritatif orangtua1,040, pendidikan orangtua 1,140, dan jumlah saudara1,182 lebih kecil dari 10, sedangkan nilai toleransi semua variabel bebas lebih dari $10 \%(0,1)$ yang berarti tidak terjadi korelasi antar variabel bebas yang nilainya lebih dari $90 \%$, dengan demikian dapat disimpulkan bahwa tidak terdapat gejala multikolinieritas antar variabel bebas dalam model regresi.

\begin{tabular}{crrr}
\multicolumn{1}{c}{ Berdasar hasil uji } & \multicolumn{2}{c}{ heterokedastistas } \\
menunjukkan & tidak & terjadi & masalah \\
heterokedastistas, & & melainkan & non
\end{tabular}
heterokedastistas atau homosedastisitas, karena nilai signifikansi untuk variabel pola asuh orangtua 0,221 , pendidikan orangtua 0,177 , dan jumlah saudara 0,065 menujukkan $\mathrm{p}>0,05$. hal ini berarti tidak terjadi penyimpangan asumsi klasik heterokedastisitas pada model regresi yang dibuat, dengan kata lain menerima hipotesis homoskedastisitas.

Hasil pengujian hipotesis 1 telah membuktikan terdapat peran secara bersamasama antara pola asuh otoritatif orangtua, pendidikan orangtua, dan jumlah saudara dengan kemandirian. Melalui hasil perhitungan yang telah dilakukan dengan menggunakan taraf signifikan $1 \%$ atau 0,01 , diperoleh $\mathrm{R}^{2} \quad 0,396$ dengan Signifikansi $=0,000(0,000<0,01)$. Pola asuh otoritatif orangtua, pendidikan orangtua, dan jumlah saudara secara bersama-sama berperan sangat signifikan terhadap kemandirian.

Hasil penelitian didapatkan nilai koefisien determinasi $\left(\mathrm{R}^{2}\right)$ 0,396. Berdasarkan hal tersebut, maka pola asuh otoritatif orangtua, pendidikan orangtua, dan jumlah saudara berperan pada kemandirian sebesar 39,6\%. Adapun sisa sebesar $60,4 \%$ dipengaruhi oleh variabel lain diluar variabel penelitian ini.Sumbangan efektif pola asuh otoritatif orangtua, pendidikan orangtua, dan jumlah saudara dilihat dari $\mathrm{R}^{2}$ change didapatkan sumbangan efektif sebagai berikut: pola asuh otoritatif orangtua 0,108 atau $10,8 \%$, pendidikan orangtua sumbangan efektifnya 0,84 atau $8,4 \%$, dan jumlah saudara memberikan sumbangan efektif sebesar 0,204 atau 20,4\%

Aspek-aspek pola asuh otoritatif seperti penerapan peraturan, kelancaran komunikasi, mengakui atau menghargai keberadaan anak, hadiah dan hukuman mempunyai hubungan aspek-aspek kemandirian. Artinya bahwa ada pengaruh antara variabel pola asuh otoritatif orangtua, pendidikan orangtua, dan jumlah saduara terhadap kemandirian. Semakin tinggi pola asuh otoritatif orangtua, pendidikan orangtua, dan jumlah saduara, maka akan semakin tinggi pula kemandirian. Sebaliknya semakin rendah pola asuh otoritatif orangtua, pendidikan orangtua, dan jumlah saduara, maka akan semakin rendah pula kemandirian.

Hasil ini mendukung penelitian yang dilakukan oleh Hurlock (1995) yang menjelaskan bahwa orang tua yang memiliki nilai budaya yang terbaik dalam memperlakukan anaknya adalah dengan cara yang demokratis, selain itu Hurlock (1995) juga berpendapat bahwa hubungan yang menyenangkan, pertentangan dan pergesekan antara saudara kandung merupakan faktor pembantu kemandirian. Pendapat selanjutnya 


\section{POLA ASUH OTORITATIF ORANGTUA, PENDIDIKAN ORANGTUA, JUMLAH SAUDARA, KEMANDIRIAN}

oleh Desmita (2010) bahwa iklim intelektual keluarga, merujuk pada sejauh mana keluarga memberikan kemudahan bagi perkembangan intelektual anak. Orang tua akan memberikan pendidikan, pembimbingan, kasih sayang, dan sikap positif yang akan berpengaruh pada kemandirian anak.

Hasil pengujian hipotesis 2 telah membuktikan terdapat peran yang positif antara Pola asuh otoritatif orangtua dengan Kemandirian. Melalui hasil perhitungan yang telah dilakukan diperoleh nilai Standardized Coefficients sebesar 0,309 dengan signifikansi 0,007 . Oleh karena signifikasi $<1 \%(0,007<$ 0,01), maka secara parsial Pola Asuh Orangtua (X1) berpengaruh secara sangat signifikan terhadap Kemandirian (Y), memberikan sumbangan efektif sebesar 10,8\% dengan mengontrol variabel pendidikan orangtua, dan jumlah saudara pada anak usia dini di TK IT Salman Al Farisi Kecamatan Umbulharjo Yogyakarta.

Pengujian ini secara statistik membuktikan bahwa pola asuh otoritattif orangtua berpengaruh positif terhadap kemandirian. Artinya bahwa ada peran yang sangat signifikan antara variabel pola asuh otoritataif orangtua terhadap kemandirian. semakin tinggi pola asuh otoritatif orangtua, maka akan semakin tinggi pula kemandirian. sebaliknya semakin rendah pola asuh otoritatif orangtua, maka akan semakin rendah pula kemandirian. Hasil ini mendukung penelitian sebelumnya yang dilakukan oleh Desmita (2010) berpendapat bahwa hubungan orang tua-anak, yang merujuk pada iklim hubungan sosial dalam keluarga, penerapan aturan, pengakuan orang tua, kelancaran komunikasi, pemberian hadian dan hukuman akan mempengaruhi kemandirian anak.

Pola asuh orang tua berperan sebagai pembimbing yang memperhatikan setiap aktivitas dan kebutuhan anaknya, terutama yang barhubungan dengan kemandirian, baik dalam lingkungan keluarga maupun lingkungan sekolah. Orang tua yang selalu bermusyawarah dalam memutuskan yang menyangkut aturan keluarga dengan memberikan kebebasan kepada anakanaknya untuk memberikan masukannya, dan hubungan komunikasi yang hangat akan mengembangkan kemandirian anak (Hurlock, 1995). Selanjutnya Andriani (2005) mengemukakan bahwa pola asuh orangtua merupakan cara dan sikap orangtua dalam membimbing dan berorientasi dengan anak-anak dalam memenuhi kebutuhannya sebagai perwujudan tanggung jawab orangtua ke arah kemandirian dan kekedewasaan anak.

Hasil penelitian ini memperkuat konsep bahwa pola asuh otoritatif orangtua akan berperan terhadap kemandirian anak. Anak yang mendapatkan kasih sayang, dukungan, perhatian, pujian, pengasuhan dan bimbingan dari orangtua dapat berkembang sesuai dengan perkembangannya serta dapat menyesuaikan diri dengan lingkungannya. Melalui pola asuh otoritatif akan membuat anak merasa aman dan nyaman, terhindar dari tekanan dalam berbagai persoalan serta hambatan, saling menghormati keputusan bersama, memberikan kebebasan berpendapat kepada anaknya, selalu berkomunikasi secara timbal balik, memberikan hukuman jika perlukan serta dalam konteks hubungan yang hangat dan sportif, untuk mendorong kemandirian anak, dengan kategori tertinggi sebesar $10(18,9 \%)$, sedang sebesar 34 $(64,2 \%)$, dan kategori rendah $9(17,0 \%)$.

Hasil pengujian hipotesis kedua dalam penelitian ini didapatkan sumbangan efektif pola asuh otoritatif orangtua sebesar 0,84 atau $8,4 \%$, dan nilai $\mathrm{p}$ sebesar 0,007 ( $\mathrm{p}<0,01$ ) sehingga disimpulkan ada peran positif dan sangat sgnifikan antara pola asuh otoritatif orangtua tehadap kemandirian dengan mengontrol variabel pendidikan orangtua, dan jumlah saudara pada anak usia dini di TK IT Salman Al Farisi Kecamatan Umbulharjo Yogyakarta.Dari hasil penelitian ini menunjukkan bahwa sebagian besar subyek mempunyai pola asuh otoritatif orangtua yang tinggi yaitu 10 (18,9\%), dengan kategori sedang

Hasil pengujian hipotesis ketiga telah membuktikan terdapat hubungan antara pendidikan orangtua terhadap kemandirian. Melalui hasil perhitungan yang telah dilakukan didapat nilai Uji terhadapa variabel Pendidikan orangtua (X2) di dapat nilai Standardized Coefficients sebesar 0,238 dengan nilai p 0,043. Olah karena $0,043<0,05$, Secara parsial Pendidikan Orangtua (X2) berperan secara signifikan terhadap Kemandirian (Y), memberikan sumbangan efektif sebesar 8,4\% dengan mengontrol variabel pola asuh otoritatif orangtua dan jumlah saudara pada anak usia dini 
di TK IT Salaman Al Farisi Kecamatan Umbulharjo Yogyakarta.

Pengujian ini secara statistik membuktikan bahwa pendidikan orangtua berperan positif terhadap kemandirian. Artinya bahwa ada peran antara variabel pendidikan orangtua terhadap kemandirian. semakin tinggi pendidikan orangtua, maka akan semakin tinggi pula kemandirian. Sebaliknya semakin rendah pendidikan orangtua, maka akan semakin rendah pula kemandirian.

Hasil ini mendukung penelitian sebelumnya yang telah dilakukan oleh Desmita (2010) menyatakan bahwa orang tua yang memiliki pendidikan tinggi akan memberikan pendidikan, pembimbingan, dan dengan kasih sayangnya kepada anaknya lebih dibandingkan dengan orang tua yang berpendidikan rendah. Orang tua yang memiliki pendidikan tinggi akan semakin tinggi pula sikap positif orang tua terhadap peran pendidikan anak. Sikap positif orang tua akan berpengaruh kepada perkembangan kemandirian anak.Papalia (2009) mengemukakan bahwa seorang ayah yang berpendidikan tinggi menjalin kedekatan dengan anaknya, kedua orang tua terlibat dalam pengasuhan anaknya. Keterlibatan dan kerja sama dari orang tua membuat keteladanan bagi anak-anaknya, sehingga anak akan mencontoh aktivitas yang dilakukan oleh orang tuanya.

Gunarsa (2004), mengemukakan bahwa tingkat pendidikan orang tua baik secara langsung maupun tidak langsung akan mempengaruhi komunikasi antara orang tua dan anak dalam lingkungan keluarga. Pendidikan orang tua yang lebih tinggi memiliki daya yang lebih besar, baik pendapatan, waktu, tenaga, dan jaringan kontak yang memungkinkan mereka terlibat lebih jauh dalam pendidikan anak. Keyakinan orang tua yang memiliki pendidikan lebih tinggi akan memberikan nilai, dan tujuan tentang pengasuhan dengan menggunakan model dan ketrampilan serta strategi dalam pemecahan masalah yang ada secara efektif dan dalam suasana yang kondusif dibandingkan dengan anak yang mempunyai orang tua yang memiliki pendidikan rendah.

Hasil penelitian ini makin memperkuat konsep bahwa pendidikan orangtua sangat berperan terhadap kemadirian anak. Iklim intelektual orangtua baik pendidikan seorang ayah atau ibu yang didapatnya dari pendidikannya dijenjang yang telah dicapainya akan mempengaruhi perkembangan kemandirian anak. Orangtua yang berpendidikan tinggi akan mempergunakan pengetahuannya untuk mencari berbagai metode untuk membimbing dan mengasuh anaknya agar bisa tumbuh mandiri demi kehidupan selanjutnya dan dapat menyesuaikan diri dengan lingkungannya. Sebaliknya bagi orangtua yang tidak berpendidikan tinggi akan membimbing dan mengasuh anaknya sesuai dengan apa yang telah didapat dari orang tuanya terdahulu, dan akibatnya anak akan mengalami hambatan dalam kemandiriannya.

Hasil pengujian hipotesis empat telah membuktikan terdapat peran positif antara Jumlah saudara dengan kemandirian. Melalui hasil perhitungan yang telah dilakukan diperoleh nilai Uji terhadap variabel Jumlah Saudara (X3) di dapat nilai Standar Coefficients sebesar 0,411 dengan nilai $\mathrm{p}$ sebesar 0,001 . Olah karena nilai $\mathrm{p}$ $<0,01$, secara parsial Jumlah Saudara (X3) berperan secara sangat signifikan terhadap Kemandirian (Y) dan memberikan sumbangan efektif sebesar 20,4\% dengan mengontrol pada variabel pola asuh otoritatif orangtua, dan pendidikan orangtua pada anak usia dini di TK IT Salaman Al Farisi Kecamatan Umbulharjo Yogyakarta.

Pengujian ini secara statistik membuktikan bahwa Jumlah saudara berperan positif terhadap kemandirian. Artinya bahwa ada pengaruh antara variabel Jumlah saudara terhadap kemandirian. Semakin tinggi peran atau dukungan terhadapjumlah saudara, maka akan semakin tinggi pula kemandirian. Sebaliknya semakin rendah dukungan Jumlah saudara, maka akan semakin rendah pula kemandirian.

Hasil ini mendukung penelitian sebelumnya oleh Hurlock (1980) jumlah saudara dalam keluarga mempengaruhi perkembangan kepribadian dan sosial anak. Santrock (2002) juga berpendapat bahwa jumlah saudara kandung dapat mempengaruhi proses sosialisasi anak dapat lebih kuat dibandingkan orang tua. Menurut Desmita (2010) hubungan saudara kandung memberikan tolok ukur untuk mengatasi tantangan dalam mencapai tujuan. Persaingan antar saudara kandung akan dapat membandingkan diri sendiri dengan orang lain. Ikatan antara saudara kandung merupakan persiapan pada kehidupan di masa mendatang, kemandirian mereka akan lebih mudah tumbuh 


\section{POLA ASUH OTORITATIF ORANGTUA, PENDIDIKAN ORANGTUA, JUMLAH SAUDARA, KEMANDIRIAN}

dan berkembang dibandingkan dengan anak tunggal.

Hasil penelitian ini memperkuat konsep tentang peran saudara dalam membentuk kemandirian. Adanya saudara kandung, akan mewarnai. Perselisihan, dan persaingan diantara saudara merupakam pembelajaran awal untuk bersosialisasi, membela prinsip moral, belajar memberikan penilaian terhadap dirinya dan saling bertoleransi sehingga anak akan mudah dalam menyelesaikan permasalahan yang terjadi di masa akan datang. Desmita (2010) berpendapat juga, sebaliknya anak yang tidak mempunyai saudara, mereka tidak mengalami pertengkaran ataupun persaingan antar saudara tidak ada dukungan antar saudara sehingga akan terhambat dalam belajar bersosialisasi dengan lingkungannya. Kurangnya dukungan saudara kandung akan menghabat perkembangan dalam bersosialisasi dengan lingkungannya.

Besaran sumbangan efektif pola asuh otoritatif orangtua, pendidikan orangtua, dan jumlah saudara terhadap kemandirian terhadap anak usia dini di TK salman Al Farisi Umbulharjo Yogyakarta sebesar 39,6\% dengan rincian pola asuh otoritatif orangtua $10,8 \%$, pendidikan orangtua sebesar $8,4 \%$, sedangkan sumbangan efektif jumlah saudara sebesar 20,4\%. Adapun sisanya sebesar $60,4 \%$ dipengaruhi oleh variabel lain diluar variabel penelitian.

\section{Simpulan}

Berdasarkan hasil analisis data dan pembahasan, maka dapat disimpulkan bahwa: pertama, terdapat peran yang sangat signifikan antara pola asuh otoritatif orangtua, pendidikan orang tua, dan jumlah saudara terhadap kemandirian secara bersama-sama. Kedua, terdapat peran yang sangat signifikan antara pola asuh otoritatif orang tua terhadap kemandirian anak usia dini dengan mengontrol variabel pendidikan orang tua dan jumlah saudara. Ketiga, terdapat peran yang signifikan antara pendidikan orang tua terhadap kemandirian anak usia dini dengan mengontrol variabel pola asuh otoritatif orang tua, dan jumlah saudara. Keempat, terdapat peran yang sangat signifikan antara jumlah saudara dengan kemandirian. Kelima, hasil penelitian menunjukkan ada peran yang sangat signifikan antara pola asuh otoritatif orang tua, pendidikan orang tua, dan jumlah saudara pada anak usia dini di TK IT Salman Al-Farisi. Hasil penelitian ini dapat dijadikan sebagai informasi bagi guru bimbingan dan konseling dalam memberikan layanan informasi kepada orangtua tentang pola asuh yang tepatagar anak dapat tumbuh dan berkembang secara optimal.

\section{Referensi}

Daradjat. Z. (2011). Ilmu Pendidikan Islam. Jakarta: Bumi Aksara.

Desmita (2010). Psikologi Perkembangan. Bandung: Remaja Rosdakarya.

Dirjen-PAUD_NI (2012). Melatih Kemandirian Dalam Kemampuan Makan Sendiri untuk Anak Usai 4-6 Tahun. Jakarta: Tim Kurikulum PAUD.

Erikson H. E. (1963). Childhood and Society. New York: Vail-Ballou Press, Ing.

Fadlillah M. \& Khorida L. (2013). Pendidikan Karakter Anak Usia Dini. Yogyakarta: ArRuzz Media.

Fatimah E. (2008). Psikologi Perkembangan. Bandung: Pustaka Setia.

Gunarsa, S. (2002). Psikologi Perkembangan. Jakarta: PT BPK Gedung Mulia.

Hurlock, E.B. (1978). Psikologi Perkembangan Anak. Penerjemah: Med. Meitasari Tjandrasa dan Muslichah Zarkasih. Jakarta: Erlangga.

Jess F., \& Gregory J. (2010). Teori Kepribadian. Edisi 7 Buku 1. Penerjemah: Handiryatno. Jakarta: Salemba Humanika.

Jess F., \& Gregory J. F.(2010). Teori Kepribadian, Edisi 7, Buku 2. Penerjemah: Smita Prathita Sjahputri. Jakarta: Salemba Humanika.

Kartono K.. (2013). Patologi Sosial. Depok: Rajagrafindo Persada.

Muthmainnah. (2012). Menata Spiritual Muslimah. Bandung: Tasdiqiya Publisher.

Muhibbin. (2010). Psikologi Pendidikan dengan Pendekatan Baru. Bandung: Remaja Rosdakarya.

Papalia O., \& Feldman. (2009). Human Development. Jakarta: Salemba Humanika.

Santrok J. W. (1995). Life-Span Development Perkembangan Masa Hidup. Alih Bahasa: Achmad Chusairi \& Juda Damanik, M.S.W. Jakarta: Erlangga. 
Santrock, J. W. (2002). Life - Span Development Perkembangan Masa Hidup. Alih Bahasa: Achmad Chusairi. Jakarta: Erlangga.

Santrock, J. W., (2008). Psikologi Pendidikan. Penerjemah: Tri Wibowo B. S. Jakarta: Prenada Media Group.

Santrock, J. W., (2009). Psikologi Pendidikan. Edisi 3 buku 1. Penerjemah: Diana Angelica. Jakarta: Salemba Humanika.

Santrock J. W. (2010). Psikologi Pendidikan . Edisi ke dua.Alih bahasa: Tri Wibowo B.S. Jakarta: Kencana Prenada Media Group.

Suwarno. (1982). Pengantar Umum Pendidikan. Jakarta: Aksara Baru.

Suyanto, S. (2005). Dasar-dasar Pendidikan Anak Usia Dini. Yogyakarta: Hikayat Publising.

Wade C, \& Travris C. (2007). Psikologi. Penerjemah: Padang Mursalin, Dinastuti. Edisi Kesembilan, Jilid 1. Jakarta: Erlangga. 